\title{
Developmental alterations of DHPG-induced long-term depression of corticostriatal synaptic transmission: switch from NMDA receptor-dependent towards CB1 receptor-dependent plasticity
}

\author{
Aisa N. Chepkova - Wiebke Fleischer • \\ Thomas Kazmierczak • Nanuli Doreulee • \\ Helmut L. Haas • Olga A. Sergeeva \\ Published online: 9 September 2009 \\ (C) Springer-Verlag 2009 \\ Erratum to: Pflugers Arch - Eur J Physiol \\ DOI 10.1007/s00424-009-0714-7 \\ The original version of this article unfortunately contained \\ a mistake. The present address of N. Doreulee was \\ incorrect. The corrected information is given below.
}

The online version of the original article can be found at http://dx.doi. org/10.1007/s00424-009-0714-7.

\footnotetext{
A. N. Chepkova $\cdot$ W. Fleischer $\cdot$ T. Kazmierczak $\cdot$ N. Doreulee $\cdot$

H. L. Haas $\cdot$ O. A. Sergeeva $(\bowtie)$

Department of Neurophysiology, Heinrich-Heine-University,

Dusseldorf 40001, Germany

e-mail: olga.sergeeva@uni-duesseldorf.de

Present Address:

N. Doreulee

Tbilisi State University,

Tbilisi, Georgia
} 